\title{
Biogeochemical specialization of Aegopodium podagraria $L$. in conditions of the Middle Volga region of Russia
}

\author{
Madina Sibgatullina* \\ Federal State Budgetary Educational Institution of Higher Education "Kazan State Power Engineering \\ University”, Department of Environmental Engineering and Workplace Safety, 420066 Kazan, Russia
}

\begin{abstract}
Properties of trace elements accumulation (Mn, $\mathrm{Fe}, \mathrm{Zn}, \mathrm{Cu}, \mathrm{Cr}$, $\mathrm{Pb}, \mathrm{Ni}, \mathrm{Co}, \mathrm{Cd}$ ) in plants of Aegopodium podagraria $\mathrm{L}$. in conditions of the Middle Volga region of Russia within the Republic of Tatarstan are considered. The biogeochemical specialization of Aegopodium podagraria L. depending on phytocenotic conditions has been established. Organospecificity of trace elements accumulation in Aegopodium podagraria $\mathrm{L}$. is revealed.
\end{abstract}

\section{Introduction}

According to the Forest Plan of the Republic of Tatarstan the Tatarstan, with its powerful energy, industrial potential and large-scale agricultural sector, occupies a special place in the Volga region of Russia, which is home to 60 million people and produces over $40 \%$ of the industrial and agricultural products of the Russian Federation. The intensive industrial and agrarian development of the natural resources of the region in recent decades has led to a significant transformation of landscapes and environmental degradation. Therefore, the assessment of the ecological state of natural systems, as standards of the natural background, in conditions of environmental degradation continues to be an urgent task.

The use of plants for biomonitoring of ecosystems status has long been known and is currently used [1, 2, 3]. Most often, mosses and lichens are used for environmental assessment purposes, which possess a number of features attractive for biomonitoring $[4,5$, $6]$, as well as woody plants $[7,8,9]$.

However, in our opinion, the most prospectively is the use of herbaceous plants, which are found as an unchanged component in all ecosystems.

The Aegopodium podagraria L. has a wide geographical dispersal and high adaptability, is a typical representative of broad-leaved forests of the Middle Volga region of Russia. These wide geographical dispersal plants are useful for biomonitoring and bioindication of the environment. In this regard, the purpose of the work was to define the natural background of trace elements in vegetation based on the biogeochemical specialization of A. podagraria.

\footnotetext{
*Corresponding author: $\underline{\text { sibmad@list.ru }}$
} 


\section{Materials and methods}

The material for the article was A. podagraria plants selected as part of a biogeochemical study of herbaceous vegetation of the Republic of Tatarstan in 2009-2011.

Plant sampling was carried out in natural places of growth - in forests of the Raif district of the Volga-Kama State Natural Biosphere Reserve, the National Park «Nizhnyaya Kama», Zelenodolsky, Arsky, Volga, Kaibitsky, Tetyushsky forestry enterprise. Research areas belong to the taiga (boreal landscape zone) and broad-leaved (subboreal northern seven-humid landscape zone) subzones.

Sampling areas were laid in different types of forest, where the A. podagraria acts as a dominant. Biological replication in one sample - 3-20 specimens. Plants were divided into separate organs - roots, leaves, caulis. Underground organs were thoroughly washed from soil particles first with tap water, then distilled water. The plants were dried to an air-dry state, were chaffed in a laboratory mill, and were ashed in a muffle oven at temperature $500^{\circ} \mathrm{C}$.

Plant organ samples and soil samples from the root-inhabited layer were analyzed. In the soil, the $\mathrm{pH}$ of the aqueous extract was determined, the content of total and mobile forms of trace elements recovered by $5 \mathrm{M}$ nitric acid and acetate-ammonium buffer solution with $\mathrm{pH} 4.8$ according to $\mathrm{RD} 52.18 .191-89$ and $\mathrm{RD} 52.18 .289-90$ respectively. Trace elements $\mathrm{Mn}, \mathrm{Fe}, \mathrm{Zn}, \mathrm{Cu}, \mathrm{Cr}, \mathrm{Co}, \mathrm{Ni}, \mathrm{Cd}, \mathrm{Pb}$ in plants were determined by atomic absorption on a Perkin Elmer Aanalyst 400 spectrophotometer according to GOST 306922000.

\section{Results and analysis}

As a result of the study, the content of trace elements in A. podagraria in the conditions of the geochemical background of the Middle Volga region within the Republic of Tatarstan was determined. The result of analyse of trace elements in A. podagraria is shown in Table.

Table. Variation and statistical indicators of trace elements content in A. podagraria plants growing in the Republic of Tatarstan, $\mathrm{mg} / \mathrm{kg}$

\begin{tabular}{|c|c|c|c|c|c|c|c|c|}
\hline TE* & $\mathbf{M} \pm \mathbf{e}$ & $\mathbf{M e}$ & Min & Max & $\mathbf{C v , \%}$ & $\begin{array}{c}\text { MPC } \\
\text { (SanPin } \\
\mathbf{2 . 3 . 2 . 1 0 7 8} \\
\mathbf{0 1 )}\end{array}$ & $\begin{array}{c}\text { Kabata- } \\
\text { Pendias A., } \\
\text { Pendias H. } \\
\text { (1989) }\end{array}$ & $\begin{array}{c}\text { Ilyin V.B. } \\
\text { (1991) }\end{array}$ \\
\hline $\mathrm{Fe}$ & $137.57 \pm 10.70$ & 142.56 & 58.66 & 214.34 & 33.00 & - & - & $20-300$ \\
\hline $\mathrm{Mn}$ & $100.90 \pm 12.31$ & 79.15 & 30.42 & 196.87 & 51.76 & - & $20-300$ & $15-150$ \\
\hline $\mathrm{Zn}$ & $27.64 \pm 5.33$ & 22.65 & 9.15 & 106.97 & 81.76 & - & $27-150$ & $15-150$ \\
\hline $\mathrm{Cu}$ & $4.24 \pm 0.48$ & 3.86 & 1.68 & 9.57 & 47.50 & - & $5-30$ & $3-40$ \\
\hline $\mathrm{Ni}$ & $2.46 \pm 0.29$ & 2.34 & 0.76 & 4.49 & 50.01 & - & $0.1-5$ & $0.1-1$ \\
\hline $\mathrm{Co}$ & $0.25 \pm 0.04$ & 0.21 & 0.09 & 0.81 & 70.77 & - & $0.02-1$ & $0.01-0.3$ \\
\hline $\mathrm{Cr}$ & $0.43 \pm 0.05$ & 0.39 & 0.17 & 0.90 & 52.81 & - & $0.1-0.5$ & $0.1-0.5$ \\
\hline $\mathrm{Pb}$ & $1.91 \pm 0.23$ & 1.45 & 0.82 & 3.46 & 50.41 & 6 & $5-10$ & $0.1-5$ \\
\hline $\mathrm{Cd}$ & $0.21 \pm 0.03$ & 0.21 & 0.05 & 0.55 & 58.58 & 1 & $0.05-0.2$ & $0.05-0.2$ \\
\hline
\end{tabular}

A number of trace elements in descending order concentrations in the A. podagraria of the studied areas forms the following sequence $(\mathrm{mg} / \mathrm{kg})$ : $\mathrm{Fe}(142.56)>\mathrm{Mn}(79.15)>\mathrm{Zn}$ $(22.65)>\mathrm{Cu}(3.86)>\mathrm{Ni}(2.34)>\mathrm{Pb}(1.45)>\mathrm{Cr}(0.39)>\mathrm{Co}(0.21) \geq \mathrm{Cd}(0.21)$. 
Concentration of trace elements in plants of $A$. podagraria is within background values and does not exceed permissible levels according to SanPin 2.3.2.1078-01 and levels in the world's vegetation $[10,11]$. A. podagraria growing in the forests of the Middle Volga region are characterized by low concentration of $\mathrm{Zn}$ and $\mathrm{Cu}$, high of $\mathrm{Cd}$.

The content of trace elements in A. podagraria varies significantly $(\mathrm{Cv}>25 \%)$, due to different ecological and geochemical growing conditions. The studied plants grew in forests of various types - oak forest, lime forest, birch forest, fir forest, elm forest formed on different types of soils.

To quantify the total capacity of the A. podagraria to trace elements accumulation, the biogeochemical activity of the A. podagraria (BCA) was calculated, which is the total value obtained by summing up of individual trace elements coefficient of biological absorption. The amount of BCA depends mainly on the amount and composition of trace elements most energetically absorbed by plants, to a lesser extent on the elements that are poorly captured by them.

Analysis of $A$. podagraria biogeochemical activity (BCA) [12] showed that the intensity of absorption of trace elements by $A$. podagraria that grew under different phytocenotic conditions varies greatly. The maximum BCA is shown by plants that grew in elm forest on rendzina soil, the minimum - plants grown in oak forest. According to the intensity of absorption of trace elements, plants growing in different phytocenotic conditions form the following series: elm forest (1264.01) > ecotone community (146.28) > fir forest (39.58) > lime forest (27.39) > birch forest (19.78) > oak forest (13.41).

The results of BCA calculation indicate that plants growing in the broad-leaved subzone have less biological activity compared to plants growing in the underground subzone.

Plants growing in the taiga subzone have a higher content of trace elements $\mathrm{Mn}, \mathrm{Fe}, \mathrm{Zn}$, $\mathrm{Cu}, \mathrm{Co}, \mathrm{Cr}$ compared to plants growing in the broad-leaved subzone. Thus, the bioticity of ashweed decreases from north to south.

All plants of $A$. podagraria barrier-free absorb $\mathrm{Mn}, \mathrm{Pb} \mathrm{Zn}, \mathrm{Ni}, \mathrm{Cu}, \mathrm{Cr}$, while $\mathrm{Mn}$ and $\mathrm{Pb}$ accumulate in leaves, $\mathrm{Zn}, \mathrm{Ni}, \mathrm{Cu}, \mathrm{Cr}$ - in flowers. Fe and $\mathrm{Co}$ are characterized by a barrier type of accumulation (fig.).

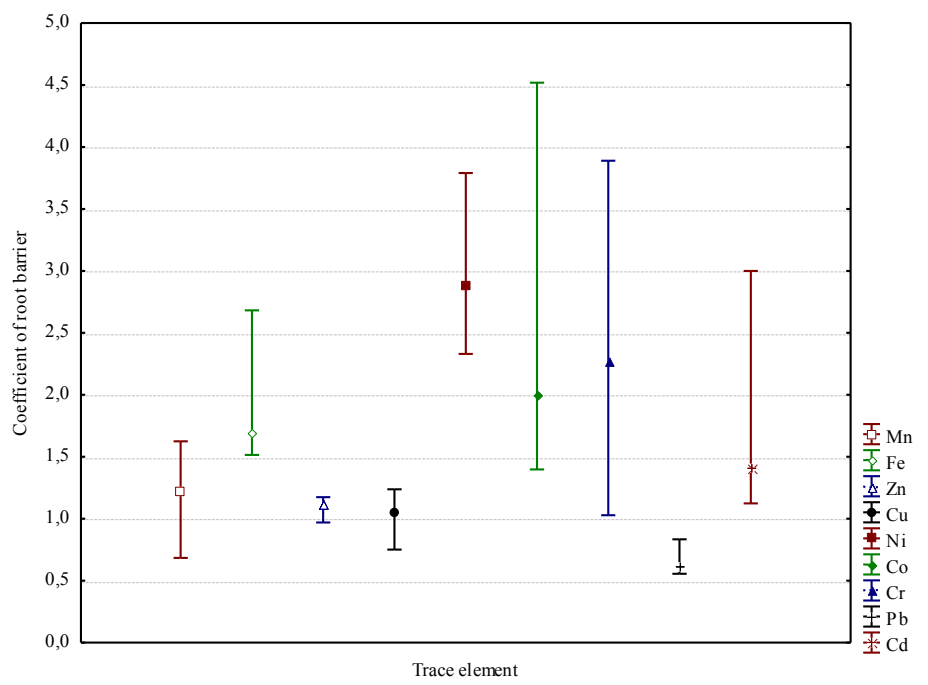

Fig. 1. Coefficients of root barrier of $A$. podagraria.

The trace element composition of $A$. podagraria growing in the forests of the Middle Volga can be considered as a reflection of the biogeochemical situation of an ecologically clean region with undisturbed natural biogeochemical cycles of elements. 


\section{References}

1. R.Bargagli, Trace elements in terrestrial plants: an ecological approach to biomonitoring and biorecovery (Moscow, 2005)

2. M.D. Ufimtseva, N.V. Terekhina, Phytoindication of the ecological state of urbogeosystems of St. Petersburg (St. Petersburg, 2005)

3. .V. Chernenkova, Response of forest vegetation to industrial pollution (Moscow, 2002)

4. E.V. Ermakova, M.V. Frontasyeva, S.S. Pavlov, E.A. Povtoreyko, E. Steinnes, Ye.N. Cheremisina, Journal of Atmospheric Chemistry, 49(1), 549-561 (2004)

5. T. Berg and E. Steinnes, Environmental Pollution, 98(1), 61-71 (1997)

6. K.N. Vergel, E.I. Goryainova, I.V. Vikhrova, M.V. Frontasieva, Ecology of urban areas, 2, 92-101 (2014)

7. S.V. Gorelova, A.R. Garifzyanov, S.M. Lyapunov, A.V. Gorbunov, O.I. Okina., M.V. Frontasyeva, Problems of biogeochemistry and geochemical ecology, 1 (12), 155-163 (2010)

8. S.V. Gorelova, E.M. Volkova, M.V. Frontasieva, Izvestiya Tula State University. Natural Sciences, 4, 232-247 (2015)

9. A.A. Kulagin, Yu.A. Shagieva, Wood plants and biological conservation of industrial pollutants (Moscow, 2005)

10. A. Kabata-Pendias, H. Pendias, Trace elements in soils and plants (Moscow, 1989)

11. V.B. Ilyin, Heavy metals in the soil-plant system (Novosibirsk, 1991)

12. I.A. Avessalomova, Geochemical indicators in the study of landscapes (Moscow, 1987) 